\title{
Pengaruh Rasio Hutang, Profit Margin, Ukuran Perusahaan, Dan Likuiditas Terhadap Financial Distress Pada Perusahaan Properti, Real Estate Dan Konstruksi Bangunan Yang Terdaftar Di Bei
}

\author{
Vieda Vira Varirera ${ }^{1}$, Suyatmin Waskito $\mathrm{Adi}^{2}$ \\ Faculty of Bussiness Economics Muhammadiyah Surakarta University ${ }^{1,2}$ \\ b200170262@student.ums.ac.id
}

\begin{abstract}
Abstrak: Financial distress merupakan keadaan kesulitan keuangan yang terjadi pada perusahaan sebelum mengalami kebangkrutan. Penelitian ini bertujuan untuk menguji pengaruh rasio hutang, profit margin, ukuran perusahaan dan likuiditas terhadap financial distress. Populasi dalam penelitian ini adalah sektor properti, real estate dan konstruksi bangunan yang terdaftar di Bursa Efek Indonesia tahun 2017-2019. Teknik pengambilan sampel dalam penelitian ini menggunakan metode purposive sampling, kemudian diperoleh 57 perusahaan sebagai sampel penelitian. Teknik analisis data yang digunakan adalah analisis regresi linier berganda dengan program software SPSS 20. Variabel financial distress diukur dengan model Zmijewsky Score, variabel rasio hutang diukur dengan debt to total asset, variabel profit margin diukur dengan net profit margin, variabel ukuran perusahaan diukur dengan log total aset dan likuiditas diukur dengan current ratio. Jenis data yang digunakan adalah data sekunder yang diperoleh dari www.idx.co.id. Hasil penelitian menunjukkan bahwa rasio hutang berpengaruh positif dan signifikan terhadap financial distress, profit margin berpengaruh negatif dan signifikan terhadap financial distress. Sedangkan variabel ukuran perusahaan dan likuiditas lainnya tidak berpengaruh signifikan terhadap financial distress.
\end{abstract}

Kata Kunci: Rasio Hutang, Profit Margin, Ukuran Perusahaan, Likuiditas dan Financial Distress

Di era globalisasi saat ini, suatu perusahaan didirikan dengan maksud untuk memperoleh keuntungan dari usaha yang dijalankan. Dalam menjalankan usahanya, mengalami jatuh bangun merupakan suatu hal yang sudah biasa untuk dihadapi oleh perusahaan. Masalah utama yang paling dihindari oleh perusahaan adalah terjadinya kebangkrutan, perusahaan akan dinyatakan menuju kebangkrutan apabila perusahaan tersebut mengalami kesulitan dalam memenuhi kewajiban. Perusahaan dianggap mengalami financial distress ketika salah satu dari kondisi ini terpenuhi yaitu perusahaan mengalami kerugian selama tiga tahun berturut-turut atau lebih dan perusahaan yang memiliki arus kas negatif selama tiga tahun atau lebih (Lakshan \& Wijekoon, 2013).

Peneliti melakukan penelitian terhadap perusahaan properti, real estate dan konstruksi bangunan yang terdaftar di Bursa Efek Indonesia karena investasi di bidang ini akan memberikan keuntungan di masa depan. Namun perkembangan perusahaan di bidang properti, real estate dan konstruksi bangunan pada tahun 2017 hingga tahun 2019 menghadapi masalah dimana banyak perumahan serta ruko yang dibangun tidak laku terjual. Perumahan serta ruko yang dibangun perusahaan yang tidak laku terjual menyebabkan laba perusahaan 
mengalami penurunan dan mengakibatkan perusahaan menghadapi masalah financial distress (Putra dan Suryanawa, 2016).

Rasio hutang merupakan sumber dana eksternal yang dapat digunakan sebagai salah satu untuk mengukur kinerja perusahaan karena rasio hutang dapat menjadi gambaran dari nilai hutang yang ada di perusahaan. Semakin besar rasio hutang pada perusahaan maka semakin tinggi pula nilai hutang suatu perusahaan, sehingga semakin besar pula investasi yang didanai oleh pinjaman. Akibatnya perusahaan harus membayar beban bunga yang lebih besar. Jika perusahaan lebih banyak menggunakan hutang untuk pembiayaan, maka akan berisiko terjadi financial distress di masa yang akan datang (Triwahyuningtias \& Muharaham, 2012). Penelitian ini menggunakan Debt to Assets Ratio (DAR) sebagai proksi untuk menghitung rasio hutang atau leverage. Penelitian oleh Ardian (2017) memperlihatkan adanya pengaruh signifikan positif Debt to Assets Ratio terhadap financial distress.

Profit margin merupakan rasio yang digunakan untuk margin keuntungan bersih yaitu perbandingan laba bersih setelah pajak terhadap penjualan. Profit margin juga menunjukkan kemampuan suatu perusahaan dalam menghasilkan laba bersih setelah dipotong pajak (Christananda dan Khairunnisa, 2017). Apabila sebuah perusahaan menghasilkan profit margin yang rendah secara terus-menerus maka akan mengakibatkan kerugian, yang akhirnya bisa menimbulkan kesulitan dalam keuangan, karena biaya yang dikeluarkan terlalu tinggi dan laba yang dihasilkan terlalu rendah. Christananda dan Khairunnisa (2017) menunjukkan bahwa profit margin mempunyai pengaruh positif signifikan dalam memprediksi kondisi financial distress.

Ukuran atau skala perusahaan merupakan variabel yang penting untuk menjelaskan pemilihan metode akuntansi. Ukuran perusahaan menggambarkan seberapa besar aset yang dimiliki oleh perusahaan. Ukuran perusahaan diukur dengan nilai pasar ekuitas, total penjualan, jumlah karyawan, total aset dan pengukuran lainnya. Idealnya ukuran perusahaan diukur dalam kaitannya dengan nilai sekarang dari total sumber daya perusahaan termasuk personilnya yang digunakan untuk tujuan produktif sendiri (Penrose, 2009). Penelitian dari Darsono (2019) menunjukkan ukuran perusahaan berpengaruh positif terhadap financial distress.

Rasio likuiditas adalah kemampuan perusahaan untuk memenuhi kewajiban jangka pendeknya secara tepat waktu (Irham, 2014). Likuiditas penting dalam mengukur seberapa likuid perusahaan dengan menunjukkan seberapa besar kemampuan perusahaan dalam melunasi hutang lancar dengan memanfaatkan aset lancar (Kasmir, 2012). Rasio likuiditas yang digunakan pada penelitian ini diukur menggunakan current ratio, rasio ini membagi jumlah aset lancar dengan utang lancar perusahaan (Widhiari dan Merkusiwati, 2015). Penelitian Pulungan (2017), Yudiawati \& Indriani (2016), Khaliq et al. (2014), dan Triwahyuningtyas \& Muharam (2012) menunjukkan bahwa Likuiditas yang diukur 
menggunakan Current Ratio berpengaruh positif signifikan terhadap financial distress. Penelitian ini bertujuan untuk menganalisis pengaruh rasio hutang, profit margin, ukuran perusahaan dan likuiditas terhadap financial distress pada perusahaan properti, real estate dan konstruksi bangunan pada tahun 2017-2019.

\section{METODE}

Metode penelitian yang digunakan dalam penelitian ini adalah kuantitatif. Penelitian kuantitatif adalah suatu proses menemukan pengetahuan yang menggunakan data berupa angka sebagai alat menganalisis keterangan mengenai apa yang ingin diketahui (Kasiram, 2008: 149) dalam bukunya Metodologi Penelitian Kualitatif dan Kuantitatif. Data yang diperlukan dalam penelitian ini berupa laporan keuangan perusahaan yang dipublikasikan dari tahun 2017 hingga tahun 2019. Data penelitian ini diperoleh dari situs www.idx.co.id selama tahun 2017-2019. Perusahaan ini terdiri dari perusahaan properti, real estate dan konstruksi bangunan.

Teknik pengambilan sampel yang digunakan dalam penelitian ini adalah teknik purposive sampling. Kriteria yang digunakan dalam penelitian ini adalah perusahaan properti, real estate dan konstruksi bangunan yang terdaftar di Bursa Efek Indonesia, yang menyajikan laporan keuangan secara lengkap dari tahun 2017 hingga tahun 2019, dan laporan keuangannya disajikan dalam mata uang rupiah (Rp) selama periode pengamatan yaitu tahun 2017 hingga tahun 2019. Sehingga didapatkan sampel untuk penelitian sebanyak 94 perusahaan dengan jumlah data 282 data dan setelah dilakukan outlier hanya 171 data yang valid dan sesuai dengan kriteria yang digunakan.

\section{VARIABEL PENELITIAN DAN PENGUKURANNYA}

\section{Financial Distress}

Financial distress merupakan suatu perusahaan yang mengalami suatu kondisi dimana keuangan perusahaan sedang dalam kondisi yang tidak baik atau sedang mengalami kesulitan keuangan, tetapi belum sampai pada tahap yang mengalami kebangkrutan. Financial distress diukur dengan menggunakan metode Zmijewski Score, Rudianto (2013) menyatakan bahwa persamaan yang digunakan oleh Zmijewski adalah sebagai berikut:

$$
X \text {-Score }=-4,3-4,5 X_{1}+5,7 X_{2}-0,004 X_{3}
$$

Dimana:

$$
\begin{aligned}
& X_{1}=\frac{\text { Laba Bersih }}{\text { Total Aset }} \\
& X_{2}=\frac{\text { Total Utang }}{\text { Total Aset }} \\
& X_{3}=\frac{\text { Aset Lancar }}{\text { Utang Lancar }}
\end{aligned}
$$

Kriteria yang digunakan dalam metode ini adalah semakin besar hasil yang didapat dengan rumus tersebut berarti semakin besar pula potensi kebangkrutan perusahaan. Dengan kata lain, jika perhitungan 
dengan metode Zmijewski Score menghasilkan nilai positif, maka perusahaan berpotensi bangkrut. Semakin besar nilai positifnya, semakin besar pula potensi kebangkrutannya.

\section{Rasio Hutang}

Rasio hutang menurut Fahmi (2014) adalah mengukur seberapa besar perusahaan dibiayai dengan hutang. Nilai rasio yang tinggi menunjukkan bahwa semakin besar penggunaan dana yang bersumber dari hutang untuk membiayai investasi pada aset perusahaan. Rasio hutang diproksikan dengan debt to ratio total assets ratio (DAR) yaitu jumlah kewajiban dibagi dengan jumlah aset. Semakin tinggi rasio hutang, maka semakin buruk kondisi perusahaan. DAR dihitung dengan rumus berikut:

\section{Profit Margin}

$$
\mathrm{DAR}=\frac{\text { Total Hutang }}{\text { Total Aset }}
$$

Profit margin adalah rasio yang digunakan untuk menunjukkan kemampuan perusahaan untuk menghasilkan keuntungan bersih setelah dipotong pajak. Profit margin menghitung sejauh mana kemampuan dari perusahaan dalam menghasilkan laba dari penjualan (Kasmir, 2010). Rasio profit margin diproksikan dengan net profit margin (NPM) yaitu perbandingan antara laba yang telah dikurangi pajak terhadap penjualan. NPM dihitung dengan rumus berikut:

\section{Ukuran Perusahaan}

$$
\mathrm{NPM}=\frac{\text { Laba Bersih Setelah Pajak }}{\text { Penjualan Bersih }} \times 100 \%
$$

Ukuran perusahaan adalah gambaran mengenai besar atau kecilnya perusahaan yang dapat dilihat dari total aset yang dimiliki perusahaan tersebut. Dalam penelitian ini ukuran perusahaan diukur dengan total assets, karena total assets menunjukkan banyaknya aset yang dimiliki oleh perusahaan, digunakan untuk membiayai sekaligus menjadi cadangan dana bagi perusahaan, untuk menjaga kelangsungan hidupnya dalam jangka panjang. Ukuran perusahaan diukur menggunakan logaritma natural total aset. Semakin kecil ukuran perusahaan, maka semakin sedikit pula aset yang dimiliki perusahaan. Perusahaan yang kecil cenderung lebih tidak stabil dalam menghadapi ancaman terjadinya financial distress. Ukuran perusahaan dihitung dengan rumus berikut:

\section{Likuiditas}

$$
\text { Ln }=\text { Total Aset }
$$

Likuiditas adalah rasio yang menunjukkan kemampuan dari perusahaan dalam memenuhi kebutuhan dana jangka pendeknya dengan aset lancar yang dimiliki oleh perusahaan tersebut. Pada penelitian ini variabel likuiditas diukur dengan menggunakan current ratio (Irham, 2013). Current ratio mengukur kemampuan perusahaan dalam memenuhi hutang jangka pendeknya dengan menggunakan total aset lancarnya. Apabila Current Ratio likuiditas perusahaan 
rendah maka kemungkinan perusahaan mengalami kondisi financial distress tinggi, sebaliknya apabila likuiditas perusahaan rendah perusahaan akan lebih mudah mengalami financial distress. Likuiditas dihitung dengan rumus berikut:

$$
\text { Current Ratio }=\frac{\text { Aset Lancar }}{\text { Utang Lancar }}
$$

\section{Analisis Regresi Berganda}

Hipotesis dalam penelitian ini akan diuji menggunakan analisis regresi berganda. Adapun model persamaan dari analisis regresi berganda yang digunakan dalam penelitian ini sebagai berikut:

$$
\mathrm{FD}=\alpha+\beta 1 \mathrm{RH}+\beta 2 \mathrm{PM}+\beta 3 \mathrm{UP}+\beta 4 \mathrm{~L}+e
$$

Keterangan:

$\begin{array}{ll}\mathrm{FD} & =\text { Financial Distress } \\ \mathrm{a} & =\text { Konstanta } \\ \beta & =\text { Koefisien } \\ \mathrm{RH} & =\text { Rasio Hutang } \\ \mathrm{PM} & =\text { Profit Margin } \\ \mathrm{UP} & =\text { Ukuran Perusahaan } \\ \mathrm{L} & =\text { Likuiditas } \\ \mathrm{E} & =\text { Standar Error }\end{array}$

\section{HASIL}

Analisis statitik deskriptif bertujuan untuk menggambarkan hasil penelitian yang dapat dilihat dari nilai minimum, maksimum, rata-rata dan standar deviasinya. Analisis statistik deskriptif dalam penelitian ini akan menggambarkan faktor-faktor yang mempengaruhi financial distress pada perusahaan properti, real estate dan konstruksi bangunan yang terdaftar di Bursa Efek Indonesia (BEI) periode 2017-2019 dengan variabel independen yang digunakan yaitu rasio hutang, profit margin, ukuran perusahaan dan likuiditas. Hasil statistik deskriptif disajikan dalam tabel berikut:

Tabel 1

Statistik Deskriptif

\begin{tabular}{|l|c|c|c|c|c|}
\hline & N & Minimum & Maximum & Mean & $\begin{array}{c}\text { Std. } \\
\text { Deviation }\end{array}$ \\
\hline RH & 148 & 0,05395 & 0,84034 & 0,4174836 & 0,19055387 \\
\hline PM & 148 & $-1,01586$ & 0,91493 & 0,1263541 & 0,24674203 \\
\hline UP & 148 & 25,04248 & 32,45446 & 29,3649282 & 1,47174899 \\
\hline $\mathbf{L}$ & 148 & 0,17855 & 7,75973 & 2,4331287 & 1,60297967 \\
\hline $\boldsymbol{F D}(\boldsymbol{Y})$ & 148 & $-4,31780$ & 0,48147 & $-2,0813140$ & 1,13390770 \\
\hline
\end{tabular}




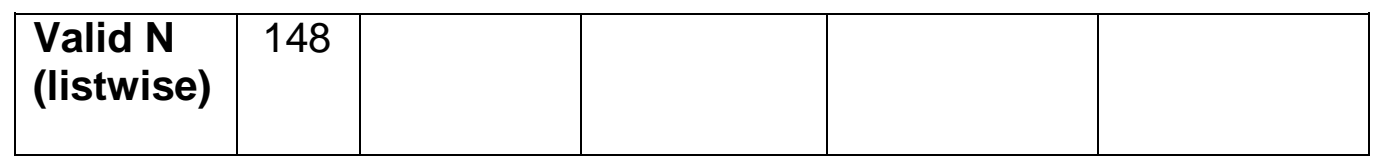

Sumber: Data Sekunder diolah, 2020.

Berdasarkan hasil deskriptif pada tabel 1 menunjukkan bahwa pada 57 sampel perusahaan properti, real estate, dan konstruksi bangunan diperoleh dari jumlah data $(\mathrm{N})$ sebanyak 148 sampel yang digunakan dalam penelitian ini. Pada Tabel Analisis Deskriptif, diketahui rata-rata financial distress sebesar $-2,0813140$, rata-rata Rasio Hutang sebesar 0,4174836, rata-rata Profit Margin sebesar 0,1263541, rata-rata Ukuran Perusahaan sebesar 29,3649282 dan rata-rata likuiditas sebesar 2,4331287 .

Berdasarkan hasil uji asumsi klasik, penelitian ini tidak mengalami penyimpangan asumsi klasik yang ditandai dengan data terdistribusi secara normal, tidak terjadi multikolinearitas, tidak ada autokorelasi dan tidak terjadi heteroskedastisitas. Data terdistribusi secara normal dibuktikan dengan jumlah data yang diuji lebih dari 30. Bukti data lolos uji asumsi klasik juga ditunjukkan oleh nilai variance inflation factor (VIF) dibawah 10 atau nilai tolerance berada diatas 0,1 . Pada uji autokorelasi menggunakan run test dapat dideteksi dengan melihat Asymp. Sig. (2tailed) sebesar 0,621 yang lebih besar dari $5 \%$ atau 0,05 yang berarti tidak terjadi autokorelasi. Selanjutnya hasil uji heterokedastisitas dengan menggunakan uji Glejser dan menunjukkan nilai signifikansi dari semua variabel lebih besar dari 0,05. Dengan penjabaran sebagai berikut, nilai signifikansi variabel Rasio Hutang 0,096 >0,05, nilai signifikansi variabel Profit Margin 0,260 > 0,05, nilai signifikansi variabel Ukuran Perusahaan $0,283>0,05$, nilai signifikansi variabel Likuiditas $0,092>0,05$. Jadi dapat disimpulkan tidak terdapat gejala heteroskedastisitas dalam model regresi yang digunakan.

Karena data penelitian sudah memenuhi seluruh asumsi klasik, maka selanjutnya dapat dilakukan analisis regresi berganda dan pengujian hipotesis. Pengujian hipotesis dilakukan dengan uji koefisien determinasi (Adjusted $R^{2}$ ), uji koefisien simultan (Uji F) dan Uji Signifikansi Parsial (Uji T). Uji koefisien determinasi $\left(\mathrm{R}^{2}\right)$ menunjukkan nilai Adjusted $R$ sebesar 0,985 . Hal ini berarti bahwa $98,5 \%$ variasi perubahan variabel financial distress dapat dijelaskan oleh variabel rasio hutang, profit margin, ukuran perusahaan dan likuiditas. Sedangkan sisanya sebesar $1,5 \%$ dijelaskan oleh variabel lain diluar model. Uji statistik $F$ menunjukkan nilai F sebesar 2349,360 dengan probabilitas 0,000 . Nilai probabilty value (sig) lebih kecil dari 0,05 yang menunjukkan bahwa model regresi layak untuk diteliti karena memenuhi goodnes of Fit. Hasil analisis regresi dengan menggunakan metode analisis regresi linier berganda dan pengujian hipotesis disajikan pada tabel 2 sebagai berikut: 
Tabel 2

Hasil Uji Analisis Regresi Berganda

\begin{tabular}{|l|c|c|c|}
\hline \multicolumn{1}{|c|}{ Variabel } & Koefisien & $\mathbf{t}_{\text {hitung }}$ & Signifikansi t \\
\hline Konstanta & $-4,175$ & $-15,884$ & 0,000 \\
\hline Rasio Hutang & 5,635 & 74,098 & 0,000 \\
\hline Profit Margin & $-0,671$ & $-12,674$ & 0,000 \\
\hline Ukuran Perusahaan & $-0,006$ & $-0,591$ & 0,555 \\
\hline Likuiditas & $-0,004$ & $-0,499$ & 0,619 \\
\hline F hitung & \multicolumn{3}{|c|}{2349,360} \\
\hline $\mathrm{R}^{2}$ & \multicolumn{3}{|c|}{0,985} \\
\hline Adjusted R ${ }^{2}$ & 0,985 \\
\hline Signifikansi F & $0,000^{\mathrm{b}}$ \\
\hline
\end{tabular}

Sumber: Data sekunder diolah, 2020

Pada tabel tersebut dapat dijelaskan hubungan antara variabelvariabel penelitian ke dalam persamaan sebagai berikut:

$\mathrm{FD}=-4,175+5,635 \mathrm{RH}-0,671 \mathrm{PM}-0,006 \mathrm{UP}-0,004 \mathrm{~L}+\mathrm{e}$

Persamaan regresi diatas dapat diinterpretasikan sebagai berikut:

f. Nilai konstanta sebesar $-4,175$ yang merupakan nilai konstanta dengan nilai negatif menandakan jika nilai variabel Rasio Hutang, Profit Margin, Ukuran Perusahaan dan Likuiditas diasumsikan konstan atau sama dengan nol maka financial distress akan mengalami penurunan.

g. Besarnya nilai koefisien variabel Rasio Hutang sebesar 5,635 dengan nilai positif, menunjukkan apabila Rasio Hutang mengalami peningkatan maka Financial Distress akan mengalami peningkatan dan juga sebaliknya apabila Rasio Hutang mengalami penurunan maka Financial Distress akan mengalami penurunan.

h. Besarnya nilai koefisien Profit Margin sebesar -0,671 dengan nilai negatif, menunjukkan apabila variabel Profit Margin mengalami peningkatan maka Financial Distress akan mengalami penurunan dan juga sebaliknya apabila Profit Margin mengalami penurunan maka Financial Distress akan mengalami peningkatan.

i. Besarnya nilai koefisien Ukuran Perusahaan sebesar -0,006 dengan nilai negatif, menunjukkan apabila variabel Ukuran Perusahaan mengalami peningkatan maka Financial Distress akan mengalami penurunan dan juga sebaliknya apabila Ukuran Perusahaan mengalami penurunan maka Financial Distress akan mengalami peningkatan.

j. Besarnya nilai koefisien Likuiditas sebesar -0,004 dengan nilai negatif, menunjukkan apabila variabel Likuiditas mengalami peningkatan maka Financial Distress akan mengalami penurunan dan juga sebaliknya apabila Likuiditas mengalami penurunan maka Financial Distress akan mengalami peningkatan. 


\section{PEMBAHASAN}

1. Pengaruh Rasio Hutang terhadap financial distress

Berdasarkan hasil penelitian pada perusahaan properti, real estate dan konstruksi bangunan yang terdaftar di BEl pada tahun 2017-2019, ditemukan bahwa variabel rasio hutang yang diproksikan dengan Debt to Total Asset Ratio (DAR) berpengaruh secara signifikan terhadap financial distress. Hal ini dapat dilihat dari nilai signifikansi t pada tabel yaitu rasio hutang menunjukkan nilai 0,000 kurang dari 0,05. Semakin tinggi nilai rasio hutang, maka kemungkinan terjadinya financial distress juga akan semakin tinggi. Hasil penelitian ini sesuai dengan penelitian dari Ardian (2017), Norisa Putri (2019), dan Chrisentya dan Julianti (2018) yang menyatakan bahwa Rasio Hutang memiliki pengaruh signifikan terhadap financial distress.

2. Pengaruh Profit Margin terhadap Financial Distress

Berdasarkan hasil penelitian pada perusahaan properti, real estate dan konstruksi bangunan yang terdaftar di BEl pada tahun 2017-2019, ditemukan bahwa variabel profit margin yang diproksikan dengan Net Profit Margin (NPM) berpengaruh secara signifikan terhadap financial distress. Hal ini dapat dilihat dari nilai signifikansi $t$ pada tabel yaitu profit margin menunjukkan nilai 0,000 kurang dari 0,05 . Semakin rendah nilai profit margin, maka kemungkinan terjadinya financial distress juga akan semakin tinggi. Hasil penelitian ini sesuai dengan penelitian dari Nurhidayah (2017) dan Aryadi (2017) yang menyatakan bahwa profit margin memiliki pengaruh secara signifikan terhadap financial distress.

3. Pengaruh Ukuran Perusahaan terhadap financial distress

Berdasarkan hasil penelitian pada perusahaan properti, real estate dan konstruksi bangunan yang terdaftar di BEl pada tahun 2017-2019, ditemukan bahwa variabel ukuran perusahaan yang diproksikan dengan logaritma natura total aset tidak berpengaruh signifikan terhadap financial distress. Hal ini dapat dilihat dari nilai signifikansi t pada tabel yaitu ukuran perusahaan menunjukkan nilai 0,555 lebih dari 0,05. Semakin tinggi nilai ukuran perusahaan, maka kemungkinan terjadinya financial distress juga akan semakin rendah. Hasil penelitian ini sesuai dengan penelitian dari Harahap (2017) dan Murni (2018) yang menyatakan bahwa ukuran perusahaan tidak memiliki pengaruh signifikan terhadap financial distress.

4. Pengaruh Likuiditas terhadap Financial Distress

Berdasarkan hasil penelitian pada perusahaan properti, real estate dan konstruksi bangunan yang terdaftar di BEl pada tahun 2017-2019, ditemukan bahwa variabel likuiditas yang diproksikan dengan current ratio tidak berpengaruh signifikan terhadap financial distress. Hal ini dapat dilihat dari nilai signifikansi t pada tabel yaitu likuiditas menunjukkan nilai 0,619 lebih dari 0,05. Semakin tinggi nilai 
likuiditas, maka kemungkinan terjadinya financial distress juga akan semakin rendah. Hasil penelitian ini sesuai dengan penelitian dari Efendi (2016), Srikalimah (2017) dan Deanisyah (2020) yang menyatakan bahwa likuiditas tidak memiliki pengaruh signifikan terhadap financial distress.

\section{KESIMPULAN}

Berdasarkan hasil penelitian pada perusahaan properti, real estate dan konstruksi bangunan pada tahun 2017-2019, maka kesimpulan yang diambil ialah terdapat dua variabel independen yang memiliki pengaruh terhadap financial distress yaitu rasio hutang yang berpengaruh secara positif dan profit margin yang berpengaruh secara negatif. Rasio hutang berpengaruh positif terhadap financial distress ditunjukkan dengan rasio hutang yang tinggi maka akan meningkatkan kemungkinan perusahaan mengalami financial distress. Pengaruh negatif profit margin juga menandakan bahwa semakin rendah profit margin maka meningkatkan kemungkinan perusahaan mengalami financial distress.

\section{DAFTAR PUSTAKA}

Ardian, A. V. (2017). Pengaruh Rasio Likuiditas, Rasio Leverage, Rasio Aktivitas dan Rasio Profitabilitas Terhadap Financial Distress Pada Perusahaan Manufaktur yang Terdaftar di Bursa Efek Indonesia periode Tahun 2013-2015. Universitas Pandanaran Semarang.

Aryadi. (2017). Pengaruh Profitabilitas, Likuiditas, Leverage dan Ukuran Perusahaan Terhadap Financial Distress. Skripsi STIE Perbanas Surabaya.

Christananda, C., \& Khairunnisa. (2017). Analisis Current Ratio dan Net Profit Margin Untuk Memprediksi Kondisi Financial Distress Perusahaan Studi Pada Perusahaan Tekstil dan Garmen yang Terdaftar di Bursa Efek Indonesia Periode 2011-2015. Karya IImiah - Skripsi S1 Universitas Telkom.

Effendi, M. A. (2016). The Power of Good Corporate Governance Teori dan Implementasi (edisi ke-2). Jakarta: Erlangga.

Fahmi, I. (2014). Analisa Kinerja Keuangan. Bandung: Alfabeta.

Harahap, L. W. (2017). Pengaruh Mekanisme Corporate Governance dan Firm Size Terhadap Kondisi Financial Distress Pada Perusahaan Property dan Real Estate yang Terdaftar di BEI Tahun 2010-2014. Jurnal Riset Akuntansi dan Bisnis Vol.17 No.2.

Hery. (2017). Teori Akuntansi Pendekatan Konsep dan Analisis. Jakarta: Grasindon.

Irham, F. (2014). Analisis Kinerja Keuangan. Bandung: Alfabeta.

Julianti, C. d. (2018). Pengaruh Profitabilitas, Leverage, Likuiditas, Firm Age dan Kepemilikan Institusional Terhadap Financial Distress. SiMAk Vol. 16 No.1 Universitas Katolik Indonesia Atma Jaya, 45-61. Kasiram, M. (2008). Metodologi Penelitian. Malang: UIN-Malang Pers. 
Kasmir. (2010). Pengantar Manajemen Keuangan. Jakarta: Kencana Prenada Media Group.

Kasmir. (2016). Analisis Laporan Keuangan. Raja Grafindo.

Khaliq, A. H. (2014). Identifying Financial Distress Firms: A Case Study of Malaysia's Goverment Linked Companies (GLC). International Journal of Economic, Finance and Management, 3(3), 141-150.

Lakshan, A. M., \& Wijekoon, W. M. (2013). The Use of Financial Rations in Predicting Corporate Failure in Sri Lanka. GSTF Journal on Business Review (GBr), 2(4), 37-43.

Mufti Gilang, D. (2019). Analisis Pengaruh Corporate Governance Perception Index, Ukuran Perusahaan dan Leverage Terhadap Financial Distress: Studi Empiris Pada Perusahaan Peserta CGPI yang Terdaftar di Bursa Efek Indonesia Tahun 2012-2016. Diponegoro Journal of Accounting, 1-10.

Murni. (2018). Analisis Faktor-Faktor yang Mempengaruhi Tingkat Financial Distress pada Perusahaan Manufaktur yang Terdaftar di BEI Tahun 2011-2014. Jurnal Akuntansi dan Bisnis, Vol. 4 (1).

Nurhidayah. (2017). Kinerja Keuangan dalam Memprediksi Financial Distress. Jurnal JJIBEKA Volume 11.

Penrose. (2009). The Theory of the Growth of the Firm Fifty Years Later. MPRA Paper No. 23180: University Of Cambridge.

Pulungan, K. P. (2017). Pengaruh Likuiditas dan Leverage Terhadap Financial Distress pada Perusahaan Sub Sektor Keramik, Porselen dan Kaca yang Terdaftar di Bursa Efek Infonesia. Jurnal Financial, 3(2), 1-9.

Putra, I. G., \& Suryanawa, I. K. (2016). Pengaruh Opini Audit dan Reputasi KAP pada Auditor Switching dengan Financial Distress sebagai Variabel Moderasi. E-Journal Akuntansi Universitas Udayana, 1120-1149.

Putri, D. S. (2020). Pengaruh Rasio Keuangan, Ukuran Perusahaan dan Biaya Agensi Terhadap Financial Distress. Jurnal Eksplorasi Akuntansi Vol.2, No.1, 2083-2098.

Putri, N., \& Mulyani, E. (2019). Pengaruh Rasio Hutang, Profit Margin, dan Ukuran Perusahaan Terhadap Financial Distress (Studi Empiris Pada Perusahaan Sektor Utama Yang Terdaftar di Bursa Efek Indonesia Tahun 2013-2017). Jurnal Eksplorasi Akuntansi Vol. 1 No. 4, 1968-1983.

Rudianto. (2013). Akuntansi Manajemen Informasi untuk Pengambilan Keputusan Strategis. Jakarta: Erlangga.

Srikalimah. (2017). Pengaruh Profitabilitas, Likuiditas dan Leverage dalam Memprediksi Financial Distress (Studi Empiris Pada Perusahaan Manufaktur yang Terdaftar di BEl Periode 2009-2013). Jurnal Akuntansi \& Ekonomi FE UN PGRI Kediri.

Tandelilin, E. (2010). Portofolio dan Investasi Teori dan Aplikasi. Yogyakarta: Kanisius. 
Triwahyuningtyas, M., \& Muharam, H. (2012). Analisis Pengaruh Struktur Kepemilikan, Ukuran Dewan, Komisaris Independen, Likuiditas dan Leverage Terhadap Terjadinya Kondisi Financial Distress (Studi Pada Perusahaan Manufaktur yang Terdaftar di Bursa Efek Indonesia Tahun 2008-2010. Diponegoro Journal of Accounting, 6 (17), 1-14.

Widhiari, N. L., \& Merkusiwati, N. K. (2015). Pengaruh Rasio Likuiditas, Leverage, Operating Capacity dan Sales Growth Terhadap Financial Distress. E-Jurnal Akuntansi Universitas Udayana, 456469.

Yudiawati, R., \& Indriani, A. (2016). Analisis Pengaruh Current Ratio, Debt To Total Asset Ratio, Total Asset Turnover dan Sales Growth Ratio Terhadap Kondisi Financial Distress. Diponegoro Journal of Management, 5(2), 1-13. 